\title{
Legal Certainty on Sale and Purchase Deed Made by the District Head of Sutera District, South Pesisir Regency as Temporary Land Deed Official (Study on Sale and Purchase Deed Number 180/AJB/CS-2017)
}

\author{
Putri Suci Amanda; Yulia Mirwati; Zefrizal Nurdin \\ Faculty of Law, Universitas Andalas Padang, Indonesia
}

http://dx.doi.org/10.18415/ijmmu.v6i2.748

\begin{abstract}
The society's need of legal certainty on land ownership nowadays is very crucial and is a vital part in society's life. Thus, every element in life related to the implementation and law enforcement must have same parameter which is the achievement of legal certainty. The problem of this research is how the legal certainty of Sale and Purchase Deed Number 180/AJB/CS-2017 in which its registration is rejected by the Head of Land Department of South Pesisir Regency. The objective of this research is to know the legal certainty of Sale and Purchase Deed Number 180/AJB/CS-2017 in which its registration is rejected by the Head of Land Department of South Pesisir Regency. The method used in this research is normative judicial. The research is analytical descriptive. All research data are analyzed by qualitative way. This research's result is Sale and Purchase Deed Number 180/AJB/CS-2017 in which its registration is rejected by the Head of Land Department of South Pesisir Regency because the deed does not fulfill objective requirement which is contradicting with the regulation of Article 12 subsection (2) Government Regulation Number 24 of 2016 regarding Amandment on Government Regulation Number 37 of 1998 regarding the Position of Land Deed Official. The deed is made out of the authority of the Head of Sutera District, South Pesisir Regency as the temporary Land Deed Official. Besides, it makes the deed illegal based on law. Therefore, the deed is no longer functioning as a proof of legal action which provides legal certainty guarantee on sale and purchase made by the parties.
\end{abstract}

Keywords: Legal Certainty; Sale and Purchase Deed; Temporary Land Deed Official

\section{Introduction}

Land is the blessing of Almighty God and also become the primary need for human. Human grows and does daily activities on the land, even after death, land is still needs as the grave. Almost every activities of human is related to land. It portrays how importand land is for human's life.

By knowing how important the land is for human and the nature of land as the God's blessing and is a national wealth, the country is asked to set the obligation, the use, the stock, and the preservation of earth, water, and space for the society's welfare at most. The attempt to set the obligation, the use, the 
stock, and the preservation of earth, water, and space by a country is stipulated in Article 33 subsection (3) in the 1945 Constitution which state that:

"Earth and water and natural wealth existing in it is owned by country and it is used for the welfare of society at most."

The society's need of legal certainty on land ownership nowadays is very crucial and is a vital part in society's life. Thus, every element in life related to the implementation and law enforcement must have same parameter which is the achievement of legal certainty. ${ }^{1}$ The intended legal certainty covers:

1. Certainty regarding person/legal institution that becomes the right holder of the land. The certainty is related to the right holder of the land is called as certainty on right subject on the land.

2. Certainty regarding land position, land borders, length, and land's width. The certainty is related to position, borders, and length as well as width of the land is called certainty regarding right object of the land. $^{2}$

According to Article 19 subsection (1) Law Number 5 of 1960 regarding Basic Regulation of Agrarian Fundamentas that:

"To guarantee legal certainty of Government, land registration is done in all around Indonesia according to the provisions set in Government Regulation."

Since the validity of Government Regulation Number 24 of 1997 regarding Land Registration, every right shift on land can only be registered to the local Land Department Office if proven with the deed made by authorized Land Deed Official. A person will not obtain a certificate and legal sale and purchase action according to law. The provision is valid for land both that has been registered or not registered yet (not yet certificated). Regarding to the unregistered land transaction, Yulia irwati states that:

"Towards the unregistered land by Land Deed Official, it is not forbidden to conduct transaction on the unregistered land if there is a remark that the land is not registered yet, and following with the transaction as well as registration is done towards the recipient of the right based on transaction (Article 25 Government Regulation Number 10 of 1961 jo Article 39 point (b) PP number 24 of 1997)."3

In order to serve society with the making of right shift deed through sale and purchase, besides it can be made by Land Deed Official, it also can be made by temporary Land Deed Official. The presence of temporary Land Deed Official is there because the opportunity of Land Deed Official formation in Regency/Municipal. The determination of Land Deed Official formation number in Regency/Municipal is set in the provision of Article 7 subsection (1) Regulation of National Land Agency Head Number 1 of 2006 regarding Implementation Provision of Government Regulation Number 37 of 1998 regarding Position Provision of Land Deed Official that states:

"Formation or need and the presence of Land Deed Official is set by Agency Head for every working area of Land Deed Official by considering factor as follows:

a. The number of district of related regency/municipal;

b. Particular legal action level regarding right on land or Ownership Right on Housing Unit as stipulated in Article 2;

c. Economic development level of related area;

d. The number of request to be taken as the Land Deed Official in regency/municipal;

e. The number of existed Land Deed Official in every regency/municipal;

\footnotetext{
${ }^{1}$ See on Satjipto Rahardjo, Law Enforcement Issue, Sinar Baru, Bandung, 1998, p 127.

${ }^{2}$ See on Bachtiar Effendie, Land Registration in Indonesia and Its Implementation Provision, Alumni, Bandung, 1993, p. 20-21.

${ }^{3}$ Yulia Mirwati, Conflict of Ulayat Land, Andalas University Presss, Padang, 2015,p. 215.
} 


\section{f. Other factors considered important by Head Agency."}

Because of the number of Land Deed Official in every Regency/Municipal in Indonesia in remote area, some areas of Regency/Municipal in Indonesia are still providing Land Deed Official formation. It also provides opportunities for District Head and Village Head to take a position of temporary Land Deed Official especially in the area which does not have Land Deed Official yet. The pointing is done by Minsiter of Agrarian and Spatial Affairs/National Land Agency (which is then called as Minister of ATR/BPN) in which its implementation is given to the Office Head of National Agency Head of West Sumatera Province.

South Pesisir Regency of West Sumatera Province in 2019 has population number of 463.923 people. ${ }^{4}$ While, the Land Deed Officials in this South Pesisir Regency are 9 people. Based on the number, it is seen that the number of Land Deed Official is still less in South Pesisir Regency. It leads to the formation opportunity of Land Deed Official in the area. Even, the opportunities are also opened for District Head and Village Head in South Pesisir Regency to take position as temporary Land Deed Official. However, the working area of temporary Land Deed Official only covers their position area as Government Official which becomes the pointing standing.

The pointing is based on the request proposed by the District Head and the Village Head. Before pointing the District Head and the Village Head as the temporary Land Deed Official, they are obliged to follow education and training firstly. The education and the training are conducted by National Land Agency to add the ability of Temporary Land Deed Official in running their position duties.

In running their position duties, temporary Land Deed Officials are independent and not sided; they also must obey ethics code and prevailing regulation, It is further explained by Habib Adjie that:

"Land Deed Official and Temporary Land Deed Official as the general official are independent, impartial, not the employee or subordinate of other parties that give them position, have authorities that have been determined based on the legal regulation which set the position (attributive) to society, country and God.."5

In daily practice, it is frequently found that temporary Land Deed Official makes right shift deed through sale and purchase which is not in line with the prevailing legal regulation. The deviation is caused by the lack of knowledge owned by related temporary Land Deed Official. The education and training given to temporary Land Deed Official is not yet enough to accommodate the implementation of authority and task of temporary Land Deed Official based on legal regulation.

Based on the evaluation, in fact, there are still deeds made by the District Head as temporary Land Deed Official in which its registration is rejected by Land Department of South Pesisir Regency. It is proven by Sale and Purchase Deed Number 180/AJB/CS-2017 made by District Head of Sutera District of South Pesisir Regency as temporary Land Deed Official. When the deed is registered in order to issue the certificate, the deed is rejected by Land Department of South Pesisir Regency. It absolutely leads to loss of some parties in the deed especially the purchaser party because he cannot propose land registration in Land Departent of South Pesisir Regency.

The deed made by the Head of Sutera District of South Pesisir Regency as the temporary Land Deed Official basically is the bonding and the excellent proof. As a bonding proof, what is written in the deed must be trusted by judge as a right thing, as long as its truth cannot be proven. As an excellent proof, the deed does not need other proof. What is written in the deed made by Sutera District Head of South Pesisir Regency as temporary Land Deed Official must be clear and cannot run or make ambiguity, so that it does not lose its proving power which is bonding and excellent.

${ }^{4}$ Central Bureau of Statistics of South Pesisir Regency, Number of Population of South Pesisir Regency, 2014-2017, 2019, https://pesselkab.bps.go.id. . Accessed on April 13, 2019 at 10:45 WIB.

${ }^{5}$ See on Habib Adjie, Creating A Thinking in Notary World \& Land Deed Official, PT Citra Aditya Bakti, Bandung, 2011, p. 102. 


\section{Theoretical Framework}

\section{Authority Theory}

Authority in a law country has a meaning that an action performed by the Government based on a legality or prevailing legal regulation. Ridwan HR explains that:

"The Government can only perform legal action if having legality or based on laws which become the aspiration manifestation of citizen. In a democratic law country, government action must obtain legitimacy from society formally stipulated in laws."

There is a difference of attribution, delegation, and mandate. H.D. van Wijk/Willem Konijnenbelt defines them as follows:

a. Attributie: toekenning van een bestuursbevoegheid door een wetgever aan een bestuursorgaan, (attribution is governance authority granting by law maker to government institution).

b. Delegatie: overdracht van een bevoegheid van het ene

c. bestuursorgaan aan een ander, (delegation is the granting of governance authority from a government institution to other government institutions).

d. Mandaat: een bestuursorgaan laat zijn bevoegheid namens hem uitoefenen door een ander, (mandate happens when government institution permits its authority is run by other institution on behalf of its)."7

\section{Legal Certainty Theory}

Regarding to legal certainty theory, it is explained by some law experts like Gustav Radburch stating that:

"we must use priority principle in which the first priority is justice and the second is benefit and the last is legal certainty. The benefit and the legal certainty cannot be contradicting with justice and the legal certainty cannot be contradicting with benefit." ${ }^{8}$

Besides, there is also another law expert's opinion namely Satjipto Rahardjo that focuses on legal certainty issue by using sociological perspective as follows:

"Every life aspect has an icon. For economy, its icon is efficiency; for medical, it is guiding human's life, etc. The icon for modern law if legal certainty. Every person will see the function of modern law as obtaining legal certainty. The society especially modern society is really in need of legal certainty in some interaction with their members and the task is put in law. Legal science is also dealing with the issue."

\section{Research Method}

To obtain the expected result in this research, the researcher used normative judicial problem approach method. The research is done towards the legal facts in Sale and Purchase Deed Number 180/AJB/CS-2017 in which its registration is rejected by Land Department of South Pesisir Regency. Then, it is accustomed to the legal regulation that sets about form, way of filling deed form, scope of authority in making a deed. The data type collected in this research is secondary data that cover official

\footnotetext{
${ }^{6}$ Ridwan HR, Nation Administration Law, PT RajaGrafindo Persada, Jakarta, 2006, p. 98.

${ }^{7}$ Ibid, p. 105.

${ }^{8}$ Achmad Ali, Exposing Legal Theory and Judicialprudence: Including Legisprudence, Prenada Media Group, Jakarta, 2009, p. 288-289.

${ }^{9}$ Ibid, p. 289-290.
} 
documents, books, research result in form of report, etc. In this research, the secondary data that the researcher uses are as follows:

\section{a. Primary Legal Material}

It is the binding legal material such as legal regulation; in this case are:

1. the 1945 Constitution;

2. Civil Code;

3. Criminal Code;

4. Law Number 5 of 1960 regarding Basic Regulation of Agrarian Fundamentals;

5. Law Number 4 of 1996 regarding Security Right on Land and Its Properties related to Land

6.Law Number 20 of 2000 regarding Amendment of Law Number 21 of 1997 regarding Acquisition Duty of Right on Land and Building;

7. Government Regulation Number 40 of 1996 regading Business Value Right, Building Value Right, and Use Right on Land;

8. Government Regulation Number 24 of 1997 regarding Land Registration;

9. Government Regulation Number 24 of 2016 regarding Amendment of Government Regulation Number 37 of 1998 regarding Regulation of Land Deed Official;

10. Government Regulation Number 36 of 2017 regarding Tax Giving on Particular Revenue in Form of Clean Property Considered as Revenue;

11. President Regulation Number 10 of 2006 regarding National Land Agency;

12. Regulation of Agrarian and Agriculture Minister Number 2 of 1962 regarding Conversion Comformation and Indonesia's Former Rights Registration on Land;

13. Regulation of National Land Agency Head Number 23 of 2009 regarding Amendment of Regulation of National Land Agency Head Number 1 of 2006 regarding Implementation Regulation of Government Regulation Number 37 of 1998 regarding Position of Land Deed Official

14. Regulation of National Land Agency Head Number 8 of 2012 regarding Amendment of Regulation of Agrarian Affairs Minister/National Land Agency Head Number 3 of 1997 regarding Implementation Regulation of Government Regulation Number 24 of 1997 regarding Land Registration.

15. Circular Letter of Agrarian Directorate of West Sumatera Province Number DA-6980/III/2F/1983.

\section{b. Secondary Legal Material}

It is material which provides explanation regarding primary legal material such as research result or law expert's opinition. In this research, secondary legal material is from books related to land registration, temporary Land Deed Official, and land deed

\section{c. Tertiary Legal Material}

It is material which provides direction and explanation on primary legal material and secondary legal material such as law dictionary, encyclopedia.

In this research, the data collection method used is document study. In doing this research, the researcher studies about library legal materials related to deed made by District Head as temporary Land Deed Official. 


\section{Legal Material Processing and Analysis}

The data obtained and checked from library research have been processed by editing and coding. In the writing of this thesis, the researcher conducts separation on the data needed and the data not needed. This editing process aims to improve the quality of the data that the researcher analyzes. Then, the researcher gives mark or code on the data that have been edited with the purpose of making the researcher easy in solving the problems.

From the data that have been obtained and arranged based on the studied aspect, analysis qualitatively is then done which is based on the legal regulation and the opinion from the experts.

\section{Literary Review}

\section{Land Registration}

According to the provision Article 1 number 1 of Government Regulation Number 24 of 1997, it is stated that:

"Land registration is a set of activities done by the Government continuously, gradually, and regularly, covering collection, processing, booking, and serving as well as preserving physical data and judicial data, in form of map and list, regarding land units, and housing units, including giving proof certificate of right for land units which already have right and ownership right on housing unit and particular rights on it."

The objectives of land registration as stipulated in Article 3 of Government Regulation Number 24 of 1997 are as follows:

1. To provide legal certainty and legal protection to the right holder of land, housing unit, and other registered rights in order to be easy to prove that he is the related right holder, thus, the certificate is given to the right holder;

2. To probide information to the involved parties including government to be easy to obtain the needed data in performing legal action regarding land units and housing units which have been registered. To perform the information function, physical data and judicial data and land unit as well as housing unit which have been registered are open for public;

3. To make the land administration in order.

The implementation of land registration all over Indonesia is based on the Government Regulation Number 24 of 1997 regarding Land Registration. The implementation of land registration is conducted by National Land Agency. It covers the activity of land registration for the first time and data maintenance of land registration. Based on the provision Article 13, the implementation of land registration for the first time is done through land registration systematically and land registration sporadically.

\section{Proving Value of Land Deed Official's Deed}

Authenticity of Land Deed Official's Deed is explained in the Decision of Supreme Court of the Republic of Indonesia Number 937/K/Sip/1970 stating that:

"Land sale and purchase deed done before Land Deed Official is considered as the cerficiate which has excellent proof." 10

Regarding to the proving power of authentic deed explained by R. Subekti is:

\footnotetext{
${ }^{10}$ Boediarto, M. Ali, Compilation of Legal Norms of Supreme Court Decision, Civil Code Half of Century, Swa Justitia, Jakarta. 2005, p. 146.
} 
"So, authentic deed not only has formal proving power which is that it is true the parties have understood on what is written in the deed, but it also has material proving power which is that what is explained is true. This is what is called as "binding" proving power. Both parties signing the deed are like binding on the position portayed in the deed."11

\section{Nullification and Cancellation of Land Deed Official's Deed}

Based on the explanation of Article 45 subsection (1) Government Regulation Number 24 of 1997 regarding Land Registration, it is stated that:

"Land Deed Official's Deed is a tool to prove that a legal action has been committed. Therefore, if the legal action is null or canceled, the deed of Land Deed Official does not function anymore as the proof of legal action by related parties; while, the legal action itself has been registered in Land Department, then the land registration according to the cancellation of the legal action is based on other proving tool, such as the decision of Court or Deed of Land Deed Official regarding new legal action."

There are two differences from the term of nullification and cancellation. The differences of both terms need to be related to the term of null and void and the term can be nulled. Null and void is the term used to value a contract if it does not fulfill objective requirements. Objective requirement is a certain thing, and the unforbidden cause. While, the term can be nulled if a contract does not fulfill a subjective condition which is all parties agree to bind themselves and ability to make a binding. ${ }^{12}$

Regarding to the term of "null and void" and the term of "can be nulled", it is further explained by Habib Adjie that:

"If subjective condition is not fulfilled, the contract can be nulled (vernietigbaar) as long as there is a demand from certain people or people in interest. If objective condition is not fulfilled, the contract is null and void (nietig), without any demand from some parties; therefore, the contract is considered never exist and not binding anyone. The contract is absolutely null can also happen if a contract made is not fulfilled whereas the legal regulation has determined the legal action must be made by the way that has been set or contradicted with public norm, because the contract is considered not exist, then there is not any base anymore for the parties to demand or argue one another with any ways and any forms. The null like this is called absolute null (absolute nietigheid)." ${ }^{\prime 3}$

\section{Discussion}

The relation between authority theory and the title chosen is that by knowing the source of authority of making a deed by District Head as the temporary Land Deed Official, it can help to solve the problems related to his authority implementation. District Head as the temporary Land Deed Official runs his authority to make authentic deed which is based on legal provision prevailing so that it is attributive. The provision that sets the authority is the Government Regulation Number 24 of 1997 regarding Land Registration, Government Regulation Number 24 of 2016 regarding Amendment on Government Regulation Number 37 of 1998 regarding Position of Land Deed Official, the Regulation of National Land Agency Head Number 8 of 2012 regarding Amendment on Minister of Agrarian Affairs/National Land Agency Head Number 3 of 1997 regarding Implementation Provision of Government Regulation Number 24 of 1997 regarding Land Registration.

\footnotetext{
${ }^{11}$ Subekti, R, Proving Law, PT Balai Pustaka, Jakarta. 2015, p. 28.

${ }^{12}$ See on Habib Adjie, Nullification and Cancellation of Notary Deed, PT Refika Aditama, Bandung, 2015, p. 64-64.

${ }^{13}$ Ibid.
} 
In Article 2 of Government Regulation Number 37 of 1998 regarding Position of Land Deed Official, it is explained that:

1. Land Deed Official is responsible for running a half of land registration ctivity by making a deed as a proof of having certain legal action done regarding right on land or ownership right on housing unit, which will be taken as a base of change registration of land registration data caused by the legal action.

2. Legal action as stipulated in subsection 1) is as follows:
a. sale and purchase;
b. exchanging;
c. granting;
d. inbreng;
e. collective right dividing;
f. Building Use Right/Use Right on Owned Land Granting;
g. Security Right granting;
h. Security Right Assignment granting.

Based on the provision, it can be known that Land Deed Official is only responsible for making authentic deed towards legal action regarding right on land or Ownership Land on Housing Unit placed in the working area. Regarding to the working area of Land Deed Official and Temporary Land Deed Official, there are differences. As set in Article 12 of Government Regulation Number 24 of 2016 regarding Amendment on Government Regulation Number 37 of 1998 regarding Position Regulation of Land Deed Official is explained that:

1. Working area of Land Deed Official is a provincial area.

2. Working area of Temporary Land Deed Official and Special Land Deed Official cover working area as Government Official that becomes the pointing standing.

3. Further provision regarding working area of Land Deed Official is set with Minister Regulation."

Based on the provision, it can be known that the authority to make a deed by District Head as Temporary Land Deed Official only covers District area which becomes its pointing standing. Then, regarding to the process of making sale and purchase set in Article 38 of Government Regulation Number 24 of 1997 regarding Land Registration that:

1. Deed making as stipulated in Article 37 subsection (1) is presented by the parties that commit legal action related and witnessed by at least 2 (two) witnesses that fulfill conditions to act as witnesses in the legal action.

2. Form, content, and way of making the deeds of Land Deed Official set by Minister."

Regarding to the mechanism of making deed, it is set further in Perkaban Number 8 of 2012 regarding Amendment of Agrarian Affairs Regulation/National Land Agency Number 3 of 1997 regarding Implementation Regulation 24 of 1997 regarding Land Registration. As known that Temporary Land Deed Official is only responsible of making deed regarding right on land or ownership right on housing unit placed in the working area. Before making a deed first, Land Deed Official must pay attention on the land status, whether the land has been certified or not certified. As in Article 39 subsection (1) Government Regulation Number 24 of 1997 regarding Land Registration, it is stated that:

"Land Deed Official rejects to make a deed, if:

1. Regarding to the land unit that has been registered or ownership right on housing unit, to him is not given authentic certificate regarding or the certificate given is not in line with the lists existing in Land Department; 
2. Regarding to land unit which has not been registered, to him is not given:

a. Right certificate as stipulated in Article 24 subsection (1) or remark letter of Village Head/Subdistrict stating that regarding to master the land unit as stipulated in Article 24 subsection (2); and

b. Remark letter that states that land unit related is not yet certified from Land Department, or for the land located in the area far from the position of Land Department, from right holder strengthened by Village Head/Subdistrict Head; or

1) One of or the parties that will conduct legal action regarding or one of witnesses as stipulated in Article 38 does not deserve or does not fulfill condition to act so;

2) One of the parties or the parties act based on the base of absolute power of attorney which naturally contains legal action of transferring right; or

3) For legal action that will be done is not obtained a permit of official or authorized institution, if the permit is needed according to prevailing laws; or

4) Object of legal action is in conflict regarding physical data and or judicial data; or

5) Other conditions are not fulfilled or prohibition disobeyed determined in the related laws."

In the process of making Sale and Purchase by District Head as Temporary Land Deed Official, there are some steps that must be paid attention. The steps cover:

1. Before making Sale and Purchase deed, District Head as Temporary Land Deed Official must check the land status whether the land has been certified or not certified.

2. Before making Sale and Purchase, the parties submit the conditions needed in making Sale and Purchase deed by District Head as Temporary Land Deed Official. The conditions needed in making Sale and Purchase as Temporary Land Deed Official which include:

a. Certificate of object ownership of sale and purchase. For the land which has been certified, right certificate on land is needed. For the land which has not been certified like former land of Customary Ownership Right in form of title of land ownership, its ownership certificate is needed and it can also be completed with Land Registration Certificate (SKPT) from Land Office of Regency/Municipal in the land position locates;

b. The identity of the parties is the seller and the buyer in form of Identity Card or Driving License or Passport, Family Card, and Marriage Book;

c. Proof of payment of Acquisition Duty of Right on Land and Building and Income Tax (PPh). The calculation of Acquisition Duty of Right on Land and Building (BPHTB) set in Law Number 20 of 2000 regarding Amendment on Law Number 21 of 1997 regarding Acquisition Duty of Right on Land and Building. Besides, the calculation of Income Tax (PPh) is set in Government Regulation Number 36 of 2017 regarding Tax Imposition of Particular Revenue in Form of Clean Wealth Considered as Income. The calculation of Acquisition Duty of Right on Land and Building is of $5 \%$ (five percents) after the price of land and building less with sale price of tax object of non tax imposition (NJOPTKP). On the other hand, Income Tax (PPh) is of 2,5\% (five percents) from the price of land and building. Acquisition Duty of Right on Land and Building and Income Tax are obliged to be paid before making sale and purchase deed by District Head as Temporary Land Deed Official.

3. Before making Sale and Purchase Deed, the buyer must make a statement that:

a. Statement that the buyer based on the transfer of right does not become right holder on land exceeding the maximum provision of land mastery according to the prevailing legal provision;

b. Statement that the buyer based on the right transfer does not the right holder of absentee according to prevailing legal provisions; 
c. Statement that if the statement as stipulated in a and b is not true, then the exceeded land or absentee land does not become landreform object.

d. Statement that as a right recipient is ready to bear the legal consequence if the statement as stipulated in $\mathrm{a}$ and $\mathrm{b}$ is not true.

4. In term of permit needed from related parties for right transfer, the permit must be obtained firstly before making sale and purchase deed by District Head as temporary Land Deed Official.

5. Towards the certified land, it is obliged to check certificate adjustment of right on land or Ownership Right on Housing Unit regarding to the existing list in local Land Office before making Sale and Purchase by District Head as Temporary Land Deed Official.

6. The form of sale and purchase deed and the way of filling deed forms are based on the provision of Perkaban Attachment Number 8 of 2012 regarding Amendment on Agrarian Affairs Regulation/National Land Agency Head Number 3 of 1997 regarding Implementation Provision of Government Regulation Number 24 of 1997 regarding Land Registration.

7. The making of sale and purchase deed is presented by seller and buyer or can be presented by power recipient followed by written power of attorney as in line with prevailing legal regulation.

8. Sale and Purchase Deed is obliged to be read and explained of deed content, the intention of deed making and the process of registration which is then done by District Head of Temporary Land Deed Official to the parties. The reading of sale and purchase deed is witnessed by at least 2 (two) witnesses that fulfill conditions to act as witnesses according to prevailing regulations.

9. After the sale and purchase deed is red by District Head as Temporary Land Deed Official and has been understood its content by the parties, then the deed is signed by the parties, the witnesses, and the District Head as Temporary Land Deed Official.

10. District Head as Temporary Land Deed Official must report the deed made to Land Office to be registered at least 7 (seven) working days since the date of signation of the sale and purchase deed.

Regarding to the requirements of land registration process, it is set in Regulation Attachment of National Land Agency Head Number 1 of 2010 regarding Standard of Service and Land Setting. The requirements of land registration are as follows:

1. Proposal form of registration is the first that must be prepared by National Land Agency containing identity, width, location, and the use of land proposed, the statement that the land is not in conflict, and the statement of being mastered physically which has been completed and signed by the appelant or its attorney;

2. Power of attorney if the process of working is given to others;

3. Copy of identity (Identity Card and Family Card) of appelance and power if it is given, which has been confirmed with its original one by the officer;

4. The original ownership proof of land/customary ownership right/former customary ownership right.

5. Copy of Notification Letter of Loan Tax on Land and Building (SPPT PBB) in ongoing year which has been confirmed with its original one by officer and the submission of Payment Proof of Acquisition Duty of Right on Land and Building (SSB BPHTB);

6. Attaching Income Tax Payment (SSP PPh) as in line with the provision.

Sale and Purchase Deed Number 180/AJB/CS-2017 is made by District Head of Sutera Head of South Pesisir Regency as Temporary Land Deed Official. Besides, the land which becomes the object of sale and purchase contract is not registered yet. When doing first land registration in Land Office of South Pesisir Regency, the deed is then rejected as the base of land registration because the land is made out of the authority of District Head as Temporary Land Deed Official.

Based on Sale and Purchase Deed Number 180/AJB/CS-2017, it can be known that the land which becomes the object of sale and purchase contract is located in Lengayang District. While, the deed 
is made by Sutera District Head of South Pesisir Regency as Temporary Land Deed Official. By referring to Article 12 subsection (2) of Government Regulation Number 24 of 2016 regarding Amendment on Government Regulation Number 37 of 1998 regarding Position Regulation of Land Deed Official, it can be known that the authority of District Head as Temporary Land Deed Official in making a deed, the Land Deed Official only covers the area of district which becomes the pointing standing. Based on the provision, it can be known that the making of Sale and Purchase Deed Number 180/AJB/CS-2017 is contradictory with the prevailing legal regulation.

If related to Article 1320 of Civil Code which sets about the legal condition of a contract, it can be known that Sale and Purchase Deed Number 180/AJB/CS-2017 does not fulfill objective condition which is contradicting with prevailing legal provisions. As the consequence of not fulfilling the condition, the deed becomes null and void. Without any request from the parties, the deed itself is considered never exist and there is no standing for the parties to demand one another by any way and any form.

Furthermore, in the explanation of Article 45 subsection (1) of Government Regulation Number 24 of 1997 regarding Land Registration, it is stated that:

"Deed of Land Deed Official is a tool to prove that legal action has been committeed. Therefore, if the legal action is null or canceled, the deed of Land Deed Official does not function anymore as the proof of legal action which is nulled by related parties while the legal action has been registered in Land Office, then the land registration according to the nullification of the legal action must be based on other proving tools, such as the decision of Court or deed of Land Deed Official regarding new legal action."

Based on the provision, it can be known that Sale and Purchase Deed 180/AJB/CS-2017 made by Sutera District Head of South Pesisir Regency as Temporary Land Deed Official does not function as a proof of a legal action. Thus, when proposing first land registration to Land Office of South Pesisir Regency, the deed is rejected because it cannot be made as a standing in land registration.

The guarantee of legal certainty is needed by the parties in the transfer process of right on land through sale and purchase. If related to legal certainty theory, the society feels secure in doing land sale and purchase with the presence of land certainty. The deed signed by the parties before the authorized officer has binding and excellent proving power. By making Sale and Purchase Deed Number 180/AJB/CS-2017 out of the authority of Sutera District Head of South Pesisir Regency as Temporary Land Deed Official, it causes the deed not function as a proof of legal action. Since the deed does not have proving power, then it cannot give guarantee of legal certainty towards sale and purchase done by the parties.

\section{Conclusion}

Based on the research result that the researcher has explained, it can be concluded that:

1. Sale and Purchase Deed Number 180/AJB/CS-2017 does not fulfill the legality of objective condition of a contract which is contradictory with legal provisions prevailing. The deed is made out of the authority of Sutera District Head of South Pesisir Regency as Temporary Land Deed Official so that it makes the deed null and void.

2. Sale and Purchase Deed Number 180/AJB/CS-2017 does not function as a proof of legal action. Because the deed does not have proving power, it cannot provide guarantee of legal certainty on the sale and purchase done by the parties. 


\section{References}

Books

Adjie, Habib.(2011). Creating A Thinking in Notary World \& Land Deed Official, PT Citra Aditya Bakti, Bandung.

Adjie, Habib.(2015). Nullification and Cancellation of Notary Deed, PT Refika Aditama, Bandung.

Ali, Achmad. (2009)., Exposing Legal Theory and Judicialprudence: Including Legisprudence, Prenada Media Group, Jakarta.

Boediarto, M. Ali.(2005). Compilation of Legal Norms of Supreme Court Decision, Civil Code Half of Century, Swa Justitia, Jakarta.

Effendie, Bachtiar. (1993). Land Registration in Indonesia and Its Implementaion Provision, Alumni, Bandung.

HR, Ridwan.(2006). Nation Administration Law, PT RajaGrafindo Persada, Jakarta.

Mirwati, Yulia.(2015). Conflict of Ulayat Land, Andalas University Press, Padang.

Subekti, R.(2015). Proving Law, PT Balai Pustaka, Jakarta.

\section{Legislation}

Circular Letter of Agrarian Directorate of West Sumatera Province Number DA-6980/III/2F/1983.

Civil Code;

Criminal Code;

Government Regulation Number 24 of 1997 regarding Land Registration.

Government Regulation Number 24 of 2016 regarding Amendment of Government Regulation Number 37 of 1998 regarding Regulation of Land Deed Official.

Government Regulation Number 36 of 2017 regarding Tax Giving on Particular Revenue in Form of Clean Property Considered as Revenue.

Government Regulation Number 40 of 1996 regading Business Value Right, Building Value Right, and Use Right on Land.

Law Number 20 of 2000 regarding Amendment of Law Number 21 of 1997 regarding Acquisition Duty of Right on Land and Building.

Law Number 4 of 1996 regarding Security Right on Land and Its Properties related to Land.

Law Number 5 of 1960 regarding Basic Regulation of Agrarian Fundamentals.

President Regulation Number 10 of 2006 regarding National Land Agency. 
Regulation of Agrarian and Agriculture Minister Number 2 of 1962 regarding Conversion Comformation and Indonesia's Former Rights Registration on Land.

Regulation of National Land Agency Head Number 23 of 2009 regarding Amendment of Regulation of National Land Agency Head Number 1 of 2006 regarding Implementation Regulation of Government Regulation Number 37 of 1998 regarding Position of Land Deed Official.

Regulation of National Land Agency Head Number 8 of 2012 regarding Amendment of Regulation of Agrarian Affairs Minister/National Land Agency Head Number 3 of 1997 regarding Implementation Regulation of Government Regulation Number 24 of 1997 regarding Land Registration the 1945 Constitution.

\section{Internet}

Central Bureau of Statistics of South Pesisir Regency, Number of Population of South Pesisir Regency, 2014-2017, 2019, https://pesselkab.bps.go.id,. Accessed on April 13, 2019 at 10:45 WIB.

\section{Copyrights}

Copyright for this article is retained by the author(s), with first publication rights granted to the journal. This is an open-access article distributed under the terms and conditions of the Creative Commons Attribution license (http://creativecommons.org/licenses/by/4.0/). 